\title{
Public transportation: a method for decreasing the traffic load in large cities
}

\author{
S. A. Tabatabaie ${ }^{1}$ \& A. A. Davoodi ${ }^{2}$ \\ ${ }^{I}$ Faculty of Engineering, Shahid Chamran University, Iran \\ ${ }^{2}$ Faculty of Engineering, Dezful Azad University, Iran
}

\begin{abstract}
The use of private vehicles in large cities has been increased extensively in recent years due to economical development. This results in a heavy traffic load and consequently high pollution in the center of the cities. This is considered to be one of the most significant problems in modern urban management. In this paper, impacts of public transportation on fuel consumption, pollution and traffic load in Ahwaz city are discussed. In addition, private and public bus networks in Ahwaz are compared both to each other and to the international standards. Eventually, a methodology to enhance bus transportation networks in large cities is introduced.
\end{abstract}

Keywords: public transportation, pollution, environment, private vehicle.

\section{Introduction}

Lack of proper development of public transportation systems in cities has led to increased use of private vehicles [1]. Fuel consumption impacts on the economy and air pollution have made the public transportation system a vital issue to be studied. The public transportation system consists of subways, light rail transits (LRT), buses, minibuses and taxies. Buses are considered as the main body of traffic systems in most of the world cities. [2]

Data for the period 2005-2006 indicate that 81.7 million people per year, equivalent to 224000 people per day, were using the bus network system in Ahwaz. This represents $9 \%$ of the whole transportation in the city [3]. 


\section{Methodology}

First a review of the current literature was carried out. Data about the bus network system of Ahwaz city were collected by using various required statistical forms adapted for this matter. The collected data were analyzed and proper solutions based on the analysis of the results have been proposed.

\section{Importance of public transportation}

An easy, safe, convenient and economical urban transportation system is of primary importance in urban planning. As the general economical situation is improved, the significance of the public transportation system is increased accordingly. The public transportation system was able to solve people's transportation needs easily in small communities until 1970. However, it is still considered one of the best alternatives to solve current traffic and consequent environmental problems. The ratio of private car owners was 184 per one thousand in 1970, and increased to 451 in 1997. This indicates a remarkable increase of private cars in Ahwaz city [4]. This phenomenon results in the following problems:

1) Increase of travel times for both private and public vehicles.

2) Pollution (air, noise).

3) Traffic security reduction.

4) Lack of sufficient required parking areas.

The widening of streets is not sufficient to overcome the above-mentioned problems. Public transportation systems can be one of the best solutions in this regard. Private vehicles occupy more area compared to public vehicles. For example a private car requires an area of about $7 \mathrm{~m}^{2}$ for every person whereas a bus needs about $1.2 \mathrm{~m}^{2}$ area for every person [5]. Providing a safe, convenient, and efficient public transportation system in a city leads to unity of the community to solve traffic and environment problems. [6]

\section{Comparison between buses and private cars in terms of fuel consumption and environmental pollution}

Using private vehicles instead of public ones results in environmental pollution [1]. Buses may be considered as the most efficient and flexible transportation system in cities and can solve traffic and pollution problems very well in cities with a population of less than half a million [7].

Studies carried out in Lisbon city show that:

1) The fuel consumption of private vehicles is six times more than that of public vehicles (buses).

2) The spread of CO and VOC gases produced by private vehicles is 2 to 3 times more than that of buses.

3) Private vehicles produce more $\mathrm{NO}_{\mathrm{x}}$ and $\mathrm{PM}$ gases than buses [1]. 
Table 1: $\quad$ Pollution production per day in Ahwaz [8].

\begin{tabular}{|c|c|c|c|c|c|}
\hline Vehicle & $\mathrm{CO}(\mathrm{kg})$ & $\mathrm{HC}(\mathrm{kg})$ & $\mathrm{NOx}(\mathrm{kg})$ & Sox $(\mathrm{kg})$ & Particles(ppm) \\
\hline $\begin{array}{c}\text { Private } \\
\text { car }\end{array}$ & 464877 & 1993 & 17931 & 8367 & 1593 \\
\hline Taxi & 23625 & 102 & 912 & 4253 & 87 \\
\hline $\begin{array}{c}\text { Mini } \\
\text { bus }\end{array}$ & 260 & 605 & 972 & 792 & 476 \\
\hline Bus & 333 & 565 & 908 & 739 & 444 \\
\hline $\begin{array}{c}\text { Motor } \\
\text { cycle }\end{array}$ & 60550 & 259 & 2335 & 10899 & 225 \\
\hline
\end{tabular}

Table 2: $\quad$ Reasons for traveling within Ahwaz [3].

\begin{tabular}{|c|c|c|c|c|c|c|c|}
\hline $\begin{array}{c}\text { Purpose } \\
\text { of travel }\end{array}$ & Shopping & Education & $\begin{array}{c}\text { Visiting } \\
\text { holy } \\
\text { places }\end{array}$ & Work & $\begin{array}{c}\text { Visiting } \\
\text { relatives }\end{array}$ & $\begin{array}{c}\text { Returning } \\
\text { home }\end{array}$ & Other \\
\hline Percent & 11 & 10 & 9 & 24 & 7 & 30 & 11 \\
\hline
\end{tabular}

Air pollution caused by private vehicles is much more than that of others in Ahwaz. Table 1 shows the amount of pollution produced by various vehicles in Ahwaz based on the most recent studies. The table indicates that a considerable part of traffic pollution in Ahwaz is produced by private vehicles particularly in the center of the city. The pollution produced by the bus system, compared to others, is insignificant.

\section{Ahwaz bus network}

Ahwaz city is located in Khouzestan province, southwest of Iran. Its population is about 1.1 million. The Karoon River divides the city into eastern and western parts. Ahwaz is ranked as the fifth largest city in Iran with an area of 220 square kilometers. There are many heavy industries and oilfields that produce pollution. Therefore, Ahwaz is considered as one of the most polluted cities in the country. The city bus network was established in 1970. The network started with ten buses [8]. The reasons for people traveling within Ahwaz city are shown in Table 2.

The Ahwaz bus network consists of 79 lines in two parts (eastern and western parts of the Karoon river) covering 1659 kilometers. There are three bus terminals in the down-town area of the city where 28 out of 79 total lines are terminated (about 35\%). One hundred of the buses belong to the public sector and 99 belong to the private sector. They cover 807 and 852 kilometers, respectively.

\section{Ahwaz bus network performance}

Statistical analysis on the Ahwaz bus network service indicates that the maximum and minimum number of passengers using one route in any one day is 
2184 and 187, respectively. The number of passengers per bus is 500 on 13 routes, between 500 and 800 on 28 routes, between 1000 and 1500 on 26 routes and over 1500 on 11 routes [3].

In Ahwaz as an average, each bus runs for 11 hours a day, which is less than the rate of other Iranian cities (14-15 hours). A bus transports on average 1125 passengers daily. The total number of passengers utilizing the bus network service in Ahwaz is found to be 224000 . This shows that only $12.7 \%$ of the total passengers are covered by the bus network while in other large cities such as Tehran, Mashhad and Tabriz, the percentages are $21 \%, 27 \%$ and $29 \%$, respectively. This indicates that sufficient buses are not available in Ahwaz.

Ahwaz has a population of 1.1 million, and considering a rate of 1.5 journeys for each person, based on statistical analysis the number of buses required is 743 . This means that Ahwaz needs 544 more buses. The average speed of a bus in the city is $21.6 \mathrm{Km} / \mathrm{h}$, while according to the international standards it should be 36 $\mathrm{Km} / \mathrm{h}[1]$.

Table 3 shows the performance of the Ahwaz bus network system in each area. The data presented in this table indicates that the average number of passengers per bus for areas 1 and 2 are 1081 and 883, respectively. Thus it can be concluded that area 1 is larger and the transportation of passengers has more difficulties.

Table 3: $\quad$ Performance of Ahwaz bus network system in areas 1 and 2 [3].

\begin{tabular}{|c|c|c|c|c|c|c|c|}
\hline $\begin{array}{c}\text { Bus } \\
\text { service } \\
\text { area }\end{array}$ & $\begin{array}{c}\text { Number } \\
\text { of buses }\end{array}$ & $\begin{array}{c}\text { Number } \\
\text { of buses } \\
\text { owned by } \\
\text { private } \\
\text { sector }\end{array}$ & $\begin{array}{c}\text { Number } \\
\text { of bus } \\
\text { routes }\end{array}$ & $\begin{array}{c}\text { Length } \\
\text { of } \\
\text { covered } \\
\text { routes } \\
(\mathrm{km})\end{array}$ & $\begin{array}{c}\text { Total } \\
\text { number of } \\
\text { transported } \\
\text { passengers }\end{array}$ & $\begin{array}{c}\text { Average } \\
\text { speed }\end{array}$ & $\begin{array}{c}\text { Average } \\
\text { time of } \\
\text { bus } \\
\text { running } \\
\text { per day } \\
\text { (hours })\end{array}$ \\
\hline 1 & 108 & 57 & 42 & 807 & 132097 & 18.2 & 11.2 \\
\hline 2 & 91 & 42 & 37 & 852 & 91906 & 24.1 & 11.2 \\
\hline Total & 199 & 99 & 79 & 1659 & 224003 & 21.6 & 11.2 \\
\hline
\end{tabular}

\subsection{Comparison of public and private transportation systems in terms of transported passengers}

Buses belonging to both private and public sectors are running in Ahwaz. Their numbers are almost the same. The private sector buses, however, transport about 20000 more passengers than the public sector. The private buses are working on average one hour less than the public ones. The average number of passengers transported daily by private buses is 1249 and shown in Table 4.

It can be noted from Table 4 that the performance of private sector buses is better than that of public sector, and the number of passengers being transported by the private sector is considerable as well. This demonstrates that investment in private sector is more efficient. 
Table 4: $\quad$ Comparison of public and private transportation systems in Ahwaz (2005-2006) [3].

\begin{tabular}{|c|c|c|c|c|c|c|c|}
\hline Sector & $\begin{array}{c}\text { Number } \\
\text { of } \\
\text { buses }\end{array}$ & $\begin{array}{c}\text { Number } \\
\text { of bus } \\
\text { routes }\end{array}$ & $\begin{array}{c}\text { Length } \\
\text { of } \\
\text { covered } \\
\text { routes } \\
\text { (km) }\end{array}$ & $\begin{array}{c}\text { Number of } \\
\text { transported } \\
\text { passengers }\end{array}$ & Speed & $\begin{array}{c}\text { Percentage } \\
\text { of used } \\
\text { bus } \\
\text { capacity }\end{array}$ & $\begin{array}{c}\text { Average } \\
\text { of bus } \\
\text { daily } \\
\text { running } \\
\text { (hours) }\end{array}$ \\
\hline Public & 100 & 44 & 833 & 101595 & 22.6 & $40 \%$ & 11.6 \\
\hline Private & 99 & 35 & 826 & 122408 & 21 & $48 \%$ & 10.6 \\
\hline Total & 199 & 79 & 1659 & 224003 & 21.6 & $44 \%$ & 11.2 \\
\hline
\end{tabular}

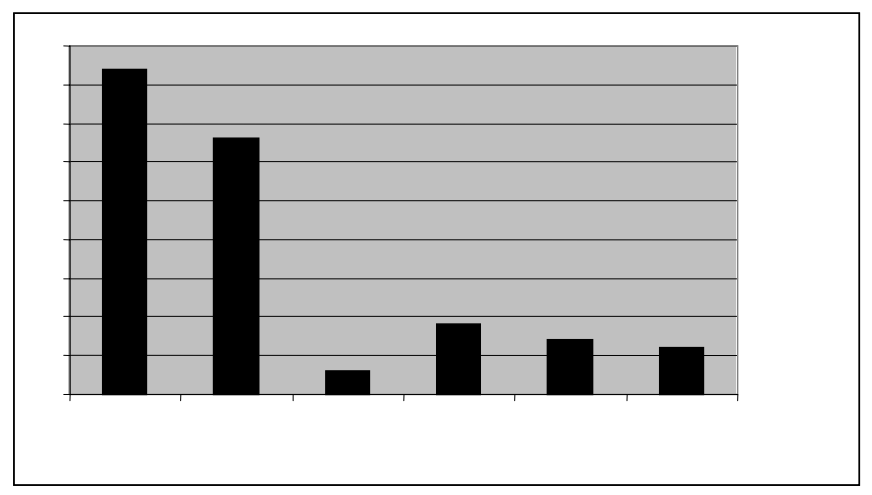

Figure 1: Percentage of passenger transportation by various vehicles in Ahwaz.

\section{Comparison of past and present passenger transportation in Ahwaz}

In 1997 , buses transported $38 \%$ of the passengers, while taxis only transported $20 \%$. However, in recent years the bus system contribution has dropped to $9 \%$ (224000 passengers per day) as shown in Figure 1 [9]. Comparison of the ratio of transported passengers in past and recent years indicates that the utilization of private vehicles has an ascending trend while the share of buses has a descending trend. This results in an increase in congestion and pollution in the city.

Table 5 shows the performance of the Ahwaz bus system in the past five years. It can be noted that the covered route length and the number of buses have increased. But the number of active buses has decreased. It is interesting that practically only half of the total buses are active in the system. This means that the Ahwaz bus system is potentially able to transport more passengers and thus it is necessary to have accurate management and planning. 
Table 5: $\quad$ Performance of the Ahwaz bus system in the past five years [3].

\begin{tabular}{|c|c|c|c|c|c|}
\hline Year & 2001 & 2002 & 2003 & 2004 & 2005 \\
\hline Number of routes & 61 & 65 & 67 & 69 & 79 \\
\hline Number of buses & 371 & 388 & 488 & 551 & 495 \\
\hline Active buses & 214 & 225 & 250 & 230 & 199 \\
\hline Number of stops & 780 & 800 & 829 & 870 & 925 \\
\hline $\begin{array}{c}\text { Rate of transportation } \\
\text { (million persons) }\end{array}$ & 68 & 85 & 74 & 68 & 81.7 \\
\hline
\end{tabular}

Public transportation planning is an integrated subsystem of the whole urban transportation planning system. Routes and terminals of the public transportation system should have a uniform integrated structure to match the increasing transport of passengers and yield better solutions to the problems in the system [10].

By the end of the fourth 5-year development plan, the public transportation share in Ahwaz should reach $70 \%$ in which the urban train and taxi shares will be $20 \%$ and $25 \%$ respectively, considering an annual growth of $4 \%$ in passenger transportation. This can be achieved by accurate planning and management.

\section{Conclusions}

Considering the yearly increase of passenger demand in Ahwaz and the population growth, the public transportation system should be enhanced. Extremely hot weather in Ahwaz and the lack of air-conditioning in buses has discouraged people from using the bus system. Actually this is the main reason for avoiding utilizing the bus system in Ahwaz. Other weak points of the public transportation system are the insufficient number of buses in the system which results in people waiting for a long time in stop stations, lack of proper supervision and control, lack of convenient distribution of buses on various routes, deficiency of proper facilities in some stop stations, and inactivity of the private sector during some hours of the day. People should be encouraged to utilize the public transportation system in order to improve social and environmental conditions. The advantages of having an efficient public system are environmental protection, safety, improvement of transportation and satisfying the needs of low-income people [11].

The following strategies are however suggested to improve the public transportation system (buses) and to encourage people to utilize this mode of transportation:

1) Using exclusive and express routes.

2) Providing a timetable in each stop station to prevent waste of time.

3) Enhancing bus efficiency, optimum use of vehicles and increasing the speed of the buses.

4) Building entrances for buses in terminals.

5) Improvement of the private sector transportation system and increase of their active hours in order to obtain a better performance. 
6) Precise control and supervision of the performance of public sector vehicles.

7) Developing further cooperation between university professors and the deputy of transportation.

8) Optimization of stop station places and shortening routes.

9) The necessity of operating the light rail transit (LRT).

\section{References}

[1] Simoes, A.M., Coelho, M.C., Silva, C.M. \& Farias, T.L., "Analysis of the environmental impact of Urban buses: application to a case study in Lisbon", Urban Transport VIII Conference, Spain, 2002.

[2] Behbahani H \& Hamed, P., "Guidelines for urban street design", Chapter 10, Published by Arkan, 2000.

[3] Andishkar Consulting Company, "Ahwaz traffic and transportation comprehensive studies", Record no 19, 2006.

[4] Reznik L.G, "The rigorous index of machines operation information of higher education Institution" .Oil and gas: Tyumen, pp.112-115, 2000.

[5] Jurauskas A. \& Susniene D., "Public transportation in the sustainable urban transport policy", Urban Transport X Conference, Germany, 2004.

[6] Vuaillat, D. Bouchet, J. Berger, "A city and a transport system for a mutual enrichment", Urban Transport X Conference, Germany, 2004.

[7] Jason S. K., James Y.L. \& Wang, C.K., "The bus rapid transit system in Taipei city rider ship forecast for the new light industrial area in Neihu", Urban Transport X Conference, Germany, 2004.

[8] Tabatabaie S.A., "Influencing factors on air pollution in Ahwaz", Urban Transport VIII Conference, Spain, 2002.

[9] Lotfi K., Tabatabaie, S.A. \& Tohidi, M., "An analysis of Ahwaz bus services system and its place in urban transportation, as well as role it plays in reducing the traffic congestion within the central core of the city", Urban Transport X Conference, Germany, 2004.

[10] Hosseini S.M., "Transportation engineering planning \& material handling analysis", Chapter 5, Published by Science \& Technology University, 2001.

[11] Munshi T., Belal, W. \& Dijst, M., "Public transport provision in Headband, India", Urban Transport X Conference, Germany, 2004. 